\title{
A Philosophical Inquiry into the Nature and Problems of Religious Experience
}

\author{
Authors: Linus Akudolu \\ Submitted: $\quad$ 15. April 2020 \\ Published: $\quad$ 17. April 2020 \\ Volume: 7 \\ Issue: 2 \\ Affiliation: Department of Philosophy and Religious Studies,Alex Ekwueme \\ Federal University. Ebonyi State, Nigeria. \\ Languages: English \\ Keywords: Religious Experience, Epistemology of Religion, Religious \\ Language, Religious Diversities. \\ Categories: Humanities, Social Sciences and Law \\ DOI: $\quad 10.17160 /$ josha.7.2.663
}

Abstract:

The paper aims at studying the nature and problems of religious experience. Religious experience is defined as a subjective experience which is interpreted in a religious circle as an encounter with God or gods or higher-order realities. The researcher identifies the features of religious experience and various activities that can enhance its manifestations. The philosophical problems of religious experience are also discussed. Despite the challenges of religious experience, the writer concludes that the experiences cannot be totally disregarded, but have to be examined discreetly in order not to be deceived, as faith without reasoning leads one to errors, deceptions and wrong belief. The work is qualitative research and the method used is philosophical analysis.

\section{JOSHA Jounalos semenes Humanities and Arts}




\title{
A PHILOSOPHICAL INQUIRY INTO THE NATURE AND PROBLEMS OF RELIGIOUS EXPERIENCE
}

\section{BY DR. LINUS OLUCHUKWU AKUDOLU}

\section{Department of Philosophy and Religious Studies, Alex Ekwueme Federal University.}

\section{Ndufu-Alike, Ebonyi State, Nigeria}

\begin{abstract}
The paper aims at studying the nature and problems of religious experience. Religious experience is defined as a subjective experience that is interpreted in a religious circle as an encounter with God or gods or higher-order realities. The researcher identifies the features of religious experience and various activities that can enhance its manifestations. The philosophical problems of religious experience are also discussed. Despite the challenges of religious experience, the writer concludes that the experiences cannot be disregarded, but have to be examined discreetly in order not to be deceived, as faith without reasoning leads one to errors, deceptions and wrong belief. The work is qualitative research and the method used is philosophical analysis.
\end{abstract}

Key Words: Religious Experience, Epistemology of Religion, Religious Language, Religious Diversities. 


\section{Introduction}

Religious experience sometimes referred to as spiritual experience, sacred experience, or mystical experience is a subjective experience that is interpreted in a religious circle as an encounter with God or gods or real contact with higher-order realities. Norman Habel et al (1993) defines it as the structured way in which a believer enters into a relation with the sacred or gain awareness with it within a particular religious sect. Many religious and mystical traditions hold that religious experiences and the knowledge that comes with them are caused by the divine agency rather than natural means. They are, therefore, divinely inspired and not by human conception. In line with their thought, such experiences are by their nature preternatural, meaning that they are beyond the natural order of things. Such experiences include prophecy, revelation, trance, dream, speaking in tongue, charismatic display, falling under the anointing and similar claims as we have in various religions.

However, Charlesworth (1988) argued that most of these experiences can be produced under drug and alcoholic influences. His argument is true as we know that drunkards and those under the influence of drugs like cocaine, Indian hemp and even the mad do have similar experiences. It becomes difficult to differentiate between real religious experiences and drug influences, but obviously, drug and alcoholic influences are not religious experiences. How can we differentiate religious experiences from drug and alcoholic influences? What are the characteristics of religious experience? Can we accept religious experiences as truth and reliable phenomenon? In the first place, the argument of Charlesword can easily be dismissed, as according to Habel's definition of the concept, any experience outside the religious context cannot be qualified as a religious experience. Nonetheless, we need to highlight the qualities of religious experience, activities that enhance the manifestations of such experiences and challenges to its credibility.

\section{Characteristics of Religious Experience}

Moore and Habel (1982) identified two classes of religious experience: the immediate and mediated forms of religious experience. Mediated experiences are those situations whereby the believer experiences the sacred through mediators as prophets, seers, totemic objects, symbols or the natural world. Immediate 
experiences, on the other hand, are where the encounter comes to the believer directly without any intermediary or mediator. Religious experiences are more impactful when the believer is directly involved. William James highlights four characteristics of religious experience as transient, ineffable, noetic and passivity. To these, we add numinous and ecstasy.

1. Transient: Religious experience is transient. Transient means fleeting, temporary or lasting for only in a short time (Hornby, 2015: 1665). The experience is temporal; the individual soon returns to a 'normal' frame of mind. It is something that happens in a few minutes, suddenly, without taking much time. It is like a flash and the subject soon returns to normalcy.

2. Ineffable: Ineffability means too great and awesome to describe in words. Religious experiences are so awesome and great to be described vividly by the person involved. The subject may have an encounter but finds it too difficult to communicate it well to depict his experience.

3. Noetic: The individual feels that he or she has learned something valuable from the experience. He feels he has gained knowledge that is normally hidden from human understanding. Therefore, it opens the individual to new knowledge, which may be strange and unusual to him.

4. Passivity: The individual is very passive. He does not initiate the experience. The experience happens to him without his conscious control. Though there are activities that are likely to arouse the experience, the individual does not in any way initiate the experience. He may engage in the activities and the experience may come or not; it may come when he expects it or when not expecting it. The fact remains that he is not in control of the encounter.

5. Numinous: This means having a strong religious and spiritual quality of God's presence. Religious experience evokes the consciousness of God's presence in the life of the subject. This consciousness may arouse fear or love for God in him. Rudolf Otto (1869-1937) in his book, The ldea of the Holy, (1923) identifies two aspects of 'numinous'. According to him, numinous experience may be mysterium tremendous, which is the tendency to invoke fear and trembling; and 
mysterium fascinans, which is the tendency to evoke love, fascination, and commitment to the divine agency of God.

6. Ecstasy: Religious ecstasy is a situation where the individual feels that his state of consciousness is altered or reduced, that he becomes less aware of physical state, while his interior mental and spiritual awareness expanded, making visions and prophecies possible. Ecstasy is a feature common in many religious experiences. In most religious experiences, the power of the fresh seems to be reduced and the spirit released to have a sacred encounter.

\section{Activities that Enhance Religious Experience}

Religious experience is not intentionally or consciously induced by the subject but certain religious activities can facilitate it. What are these activities? We may not exhaust them, but highlight the commonest ones among them:

1. Extended Religious Exercise: Various religious sects gather to worship, pray, listen to their doctrinal teachings, and have communion. When such fellowship is extended, many religious encounters become feasible. This is very common in Christian religion where gathering like camp, crusades and set apart become avenues for diverse miracles, healings, and prophecies. This is because of what is called 'cooperate anointing' and mortifying of the fresh through such long fellowship.

2. Mortification of the Fresh: Man is made up of body and soul. The soul is very powerful but is caged in the body with various bodily desires. The more one indulges in satisfying the desires of his body, the more powerful the fresh becomes while the spirit weakens. The beginning of man's self-realization is the mortification of the fresh. Once one mortifies his bodily desires especially the desires for sex, eating, drinking and worldly enjoyment, his soul gets more power over the fresh. In that state, the person becomes susceptible to diverse religious experiences.

3. Praying: Prayer is defined as a "mediums through which man empresses his desires and needs to his maker, while the maker speaks to him through the 
scripture" (Akudolu, 2018:22). Akudolu gives instances of those that lived lives of prayer and their lives characterized by miracles and diverse religious experiences. Prayer is very effective, but sins, unbelief and wrong motive militate against its efficacy.

4. Fasting: Similar to prayer is fasting, where one forbids food and stays in prayer. The lives of many religious leaders were extraordinary because of fasting and prayer. Think of Jesus Christ, Mohammed, Moses, and others. Fasting mortifies the fresh and empowers the spirit, making it easy for it to have access to spiritual realities.

5. Singing and Dancing: Music is very powerful. Religious songs and dancing are known for long as means to receiving religious experiences and miracles as its opens the spiritual door of a man. Similar stories of religious experiences coming as a consequence of singing and dancing abound in the Holy Bible, Holy Quran, Bhagavad Gita, and other Holy Writs.

6. Meditation: Meditation may be scriptural meditation, where one gives deeper thought to the contents of the scripture; it may be yoga meditation, focused attention meditation, transcendental meditation, mental or any form as we have many forms of it according to various religious traditions. Meditation of any kind can calm the mind and spirit and makes it susceptible to various religious experiences.

7. Questioning or Investigation: Socrates, Plato, Pythagoras, Thales, Empedocles, and many ancient Philosophers were known for questioning and investigating the truth. An investigative mind is always powerful and can open one to realm beyond ordinary. This is the kind of experience common in metaphysical and esoteric investigations.

\section{Problems of Religious Language}

Religion has been a problem since time immemorial. This is because religion centres on God who is invisible. Most of the religious issues are spiritual and abstract and this elicits lots of challenges to its claims. Problems of religious 
language are more of epistemological issues. Here, we shall arrange them into five headings for easy comprehension and clarity.

1. The problem of Justification: Religious experiences are not physical and cannot be verified empirically. They do not depend on our sense organs like other experiences, yet religious adherents tend to take them seriously as something real. We may, therefore, ask: What reason there is to think they are right? That is to say, is there any good reason to believe religious experience? In other words, how can we justify religious experience? One answer to this question is what is called the Argument from Religious Experience. According to the argument, religious experiences are in all relevant aspects similar to sensory experiences. Sensory experiences are excellent ground for belief about the physical world; similarly, religious experiences are excellent ground for religious belief (Swiburne, 1979; Alson 1991; Plantinga 1981 and others). Critics of this argument generally find ways in which religious experiences are different from sensory experiences, and argued that those differences are enough to undermine the evidential value of the experiences. The proponents insist that religious experience is in the domain of the spiritual and should not be judged with the instrumentality of the senses. The problem with this is that everybody is not spiritual and therefore cannot understand the religious experience.

\section{The problem of Religious Diversities with conflicting Religious}

Experiences: In sensory experience, there is a similarity in what people observe but in religious experience, there is a wide range of differences in what people claim to have seen, even within the same religious group. I cannot forget my experience in one prayer team where a lady started speaking in tongues. In the end, she prophesied to one brother, "The Holy Spirit says that you must marry me". The brother started his own speaking tongues and ended with this prophecy, "Sister, Holy Spirit says I must not marry you". Which of these two prophecies is to be accepted as true? The problem of conflicting religious experience becomes worse with the existence of diverse religious sects. What 
a particular religious group believes in is quite different from the other. How can we reconcile this? In response to this, John Hick $(1989,2006)$ adopted Kantian phenoumena and noumena. Kant (1970) has said that the phenoumena is the reality as people see it but noumena are the reality as it is which is incomprehensible. According to him, how people experience reality may differ because of certain factors, but that does not make reality non-existent. Truly, people perceive realities in diverse ways. Human frailty, condition of the mind, aspiration, background, and difference in belief can affect how people perceive and interpret issues. The work of philosophers is, therefore, to search out the truth uncorrupted. In addition to this, Alston (1991) and Plantiga (1981, 2000) argued that each religious tradition has its epistemic resources. Members within that particular religious circle understand the experience within the circle. They do not require epistemic resources outside their circle. Those within that circle understand their religious experiences, but those who are outside may not understand it. Therefore, religious experience is meaningful within a particular circle. But the problem remains unsolved: How can they help others outside their religious circle to understand their religious experiences? How can they, within the same circle reconcile their conflicting ideas since, within a particular circle, conflicting experience does happen? The case of "The Holy Spirit says you must marry me" is a typical example. More so, our society is characterized by many religious sects, how can we reconcile their conflicting views (which are products of their diverse experiences) to have a harmonious and peaceful society? These are serious challenges indeed!

3. Naturalists' Explanations for Religious Experiences: The naturalists give diverse interpretations of religious experiences which if not properly defended undermine the reality of such claims. This is because if naturalistic explanations are sufficient to explain the experience, we have no ground for believing anything beyond the naturalistic cause. Freud (1927) and Marx (1976/1977) are notable for positing such claims. Freud claimed that religious experience can be explained by his psychoanalytic theory as a mechanism having their roots in early childhood experience and psychodynamic tensions. Marx attributed 
them to materialistic economic forces. Their followers argued that religious experiences are products of the material world as what you see in material world determines the kind of dream you may have in the night. When you see a beautiful lady, you may end up dreaming having sex with such lady or another beautiful lady in your dreams. This, according them, are products of your physical experiences. In similar way, they see religious experience as the product of the mind which is the product of our brain. Our brain, being a matter, means that religious experience can be interpreted in materialist term. More recently, neurologists explain religious experience as something similar to seizure, hallucination and mental deranged which can be produced by certain narcotic drugs (Guthrie,1995). Responding to these, Gellman (2001) points out that most of these naturalistic explanations (like psychoanalytic and materialistic interpretation) are mere hypotheses, not established facts. Similarly, the effects of drug and hallucination cannot be qualified as religious experience since by our definition, religious experience must take place within a religious context. Obviously, most subjects of religious experiences are nonalcoholics, people of sound mind and integrity. The issue of dreams are easily dismissed as many dreams and religious experience take place without premeditations. Therefore, the positions of naturalist may be disregarded. But Ellwood (1999) brings up another challenge, claiming that every experience, no matter the source, corresponds to a neurological state, and therefore illusory. But if every experience corresponds to neurological state or brain state and therefore illusory, it means that everything is illusory, not only religious experience. This leads to scepticism.

4. Difficulty in convincing others to believe your Experience: We have seen that religious experiences may not be understood by persons who are not within a particular religious tradition; in that case, how can you convince someone outside your tradition to believe you? In other words, how can religious experience necessitate belief? Even within the same religious circle, there are conflicting experiences and doubts as we have noted. Some, like Oakes (1976) claim that it is epistemologically possible to form a belief based on such 
experiences, but you may also be justified in not forming a belief. According to them, if we can believe the testimonies of others concerning the event that happened when we are not there, why not a religious experience. It depends on whether the testimony is compelling enough for us to believe it or not. In that case, we have to evaluate the contents of what is said, the coherency and logicality, an epistemological and mental situation of the speaker, and then the context. Though these may be acceptable criteria, they are not so reliable as we are aware of fraudulent activities and deceits going on in various religious circles, nowadays.

5. Linguistic Problem: Another problem of religious experience is its language. The positivists, in their verifiability principles, hold that language must picture reality; for a proposition to be true, it must be verified; and it can also be falsified. An exception to these rules is analytic statements where the subject is contained in the predicate. An example of such statements is "A bachelor is an unmarried man". Here 'bachelor' means 'unmarried man'. Such a statement is always true. Religious language does not pass any of these tests and therefore regarded as meaningless. In response to this, Akudolu (2019) and Okoro (2014) hold that verifiability principles of logical positivists and empiricists are not verifiable and therefore fall victim to its claims. Religious experience is a spiritual experience and should not be judged with empirical tools. This is the main emphasis of Wittgenstein's language game (Wittgenstein, 1978). Language is like a game, every game has its language and can be judged within that context. Therefore, religious experience and language can only be judged in a religious and spiritual context.

\section{Conclusion}

From what we have done so far, we can affirm that religious experiences are subjective experiences that can have meaning within a religious context. It includes experiences like prophecy, revelation, trance, dream, speaking in tongue, charismatic display, falling under the anointing and similar claims as we have in many religions. These 
experiences are divinely inspired but can be enhanced through certain religious practices. Transience, ineffability, noetic, passivity, numinous, and ecstasy are common features of such experiences. Religious experiences are highly valued in the religious circle but have some epistemological and linguistic challenges, which we have examined. We, therefore, hold that despite all these challenges, religious experiences cannot be disregarded, but we need to examine and judge them with maturity in order not to be deceived. Faith without reasoning leads one to errors, deceptions and wrong belief.

\section{References}

Akudolu, L.O. (2018). Moving the Heart of God. Nigeria, Onitsha: Perfect Image Publishers.

Akudolu, L.O. (2019). Understanding the Nature and Problems of Metaphysics. Nigeria, Awka: Valid Publishers.

Alson, W. P. (1991). Perceiving God. Ithaca: Cornel University Press.

Charlesworth, M. (1983). "Religious Experience." Unit A: The Study Guide 2. Dakin University.

Ellwood, R. S. (1999). Mysticism and Religion. New York: Seven Bridges Press.

Freud, S. (1927). "The Future of an illusion”. In The Future of an Illusion, Civilization and its Discontents, and other Works (Vol. xxi, the Standard Edition of the Complete Psychological works of Sigmund Freud). London: Hogarth Press, pp.1-55.

Gellman, J. (2001). Mystical Experience of God. Burlington: Ashgate Publishing.

Guthrie, S.E. (1995). Faces in the Clouds: A new Theory of Religion. New York: Oxford University Press.

Habel, N. et al (1993). "Religious Experiences". In Myth, Ritual and the Sacred: Introducing the Phenomena of Religion. Underdale: University of South Australia.

Hick, John, 1989. An Interpretation of Religion: Human Responses to the Transcendent, 
London: Macmillan.

—, 2006. The New Frontier of Religion and Science: Religious Experience, Neuroscience,

and the Transcendent, New York: Palgrave Macmillan.

Hornby, A.S. (2015). Oxford Advanced Learner's Dictionary. Uk, Oxford: Oxford University Press.

Kant, Immanuel (1970). Critique of Pure Reason (Trans. Norman K. Smith). London: Macmillan and Co. Ltd.

Marx, K. (1977). Introduction to a Contribution to the Critique of Hegel's Philosophy of Right (Trans. O'Malley, J and Jolin, A.). New York: Cambridge.

Moore, B. and Habel, N. (1982). Appendix 1, When Religion Goes to School. Adelaide: SACAE, pp. 184-218.

Oakes, R.A. (1976). "Religious Experience and Rational Certainty", Religious Studies, 12 (3), pp.311-318.

Okoro, Ajanwachukwu Edward (2014). Contemporary Non-Sense Metaphysics. Nigeria, Abakilki: Ecstacy Graphics and Prints.

Otto, R. (1923).The Idea of the Holy, trans. John Harvey. London: Cambridge University Press.

Plantinga, A. (1981). "Is Belief in God properly Basic?", Nous, 15, pp.41-51. (2000). Warranted Christian Belief. New York: Oxford University Press.

Swiburne, R. (1979). The Existence of God. New York: Clarendon Press.

Wittgenstein, L. (2009). Lectures and Conversations on Aesthetics, Psychology, and Religious Belief, Cyril Barret (ed). Berkeley: University of California Press. 


\section{About the Author}

Dr. Linus Oluchukwu Akudolu is a lecturer at the Department of Philosophy/Religious Studies, Alex Ekwueme Federal University, Ndufu-Alike, Ikwo, Ebonyi State, Nigeria. He has his Diploma in Theology from Paul's University, Awka, BA, MA and Ph.D. from the Department of Philosophy, Nnamdi Azikiwe University, Awka. He also has a PGDE from National Teacher's Institute, Kaduna, all in Nigeria. He is an Anglican priest, happily married to Mrs. Nkiruka Akudolu (Nee Uzoagu). The marriage is blessed with four children. 